\title{
Contemporary Changes of Mean Annual and Seasonal River Discharges in Croatia
}

\author{
Ivan Čanjevac, Danijel Orešić
}

This paper presents the first comprehensive nationwide trend detection of mean discharges in Croatia. Over the last 30 years, global climate change has manifested itself largely in the rise of the average annual temperature, which has resulted in the changes of evapotranspiration and precipitation patterns. The consequences of those changes have been varied spatial impacts on river discharge (flow). We analysed the changes in mean river discharges in Croatia at 53 gauging hydrological stations over the most recent period from 1990 to 2009. To assess the trend, the Kendall-Theil (Sen) non-parametric trend test was carried out for the yearly and seasonal mean discharge values. We found evidence of redistribution of discharge throughout the year, an increase in autumn and winter discharges (especially on the rivers dominantly fed by snowmelt) and a decrease in summer discharge values. Furthermore, we detected a change in the month of the appearance of mean discharge maxima and minima. In most cases the changes can be explained by the changes in the regime of climate elements (temperature, precipitation, evapotranspiration) although that information should be treated with care because of the shortness of the time-series. The results are consistent with the ones from the upstream countries, i.e. Slovenia and Austria.

Key words: discharge, trends, Croatia, rivers, hydrology, geography

\section{Novije promjene srednjih godišnjih i sezonskih protoka rijeka u Hrvatskoj}

U radu se iznose rezultati prve sveobuhvatne analize suvremenih promjena srednjih mjesečnih protoka rijeka u Hrvatskoj. U posljednjih tridesetak godina globalne promjene klime uglavnom se očituju kroz porast srednje godišnje temperature zraka, što za posljedicu ima promjene u prostornoj i vremenskoj distribuciji padalina i vrijednosti evapotranspiracije. Te promjene imaju različite prostorne posljedice na protoke i protočne (riječne) režime rijeka. U ovom istraživanju analizirane su promjene srednjih protoka rijeka u Hrvatskoj na 53 hidrološke stanice od 1990. do 2009. Za analizu trenda na godišnjoj i sezonskoj razini upotrijebljen je Kendall-Theilov (odnosno Senov) test. Utvrđeno je postojanje preraspodjele protoka unutar godine, povećanje jesenskih i zimskih srednjih protoka (osobito na rijekama sa značajnijim udjelom sniježnice) i smanjenje ljetnih protoka. Uočene su i promjene u mjesecu javljanja maksimuma i minimum srednjih protoka, koje se u većini slučajeva mogu objasniti promjenama u režimu klimatskih elemenata (temperature, padalina i evapotranspiracije) iako rezultate treba uzimati s dozom opreza zbog kratkoće analiziranog niza. Rezultati istraživanja uglavnom se poklapaju s rezultatima sličnih istraživanja u nama uzvodnim zemljama (Slovenija i Austrija).

Ključne riječi: protok, trend, Hrvatska, rijeke, hidrologija, geografija 


\section{INTRODUCTION}

Over the last 30 years, global climate change has largely manifested itself in the average annual temperature rise, resulting in evaporation and precipitation pattern change. These changes have different spatial impacts on river discharge (streamflow) regimes. River discharges are the most reliable component of the hydrological cycle (from the measurement standpoint) and the analysis of long-term data can give us valuable information about trends and variations of climate in the study area (Chiew and McMahon, 1996).

According to FAO, Croatia is a country rich in water resources with around $24000 \mathrm{~m} 3 /$ year/ capita (FAO, 2012). Although Croatia has a high dependency ratio of around $65 \%$ as well, water resources are among the most vital and strategic natural resources of the country. What is the effect of (evident) climate change or oscillation on water resources in Croatia? Are there any significant trends in the discharge regimes of rivers in Croatia? These are the main underlying questions and the motivation for the study. The answers, together with other studies, should help water managers and decision-makers in Croatia. This study represents the first comprehensive nationwide assessment of the trends of mean river discharges and should be one of the starting points for future smaller scale research projects.

\section{RESEARCH AREA AND TIME FRAMEWORK}

The research area is Croatia, i.e. rivers in Croatia. More than $50 \%$ of the country is covered by karst with specific hydrological processes. Mountainous, western and southern Croatia largely belong to the Dinarides (Dinaric karst) with the surface and subsurface drainage into the Adriatic Sea. Eastern, northern and central parts of Croatia are largely non-karst areas with a well-developed surface drainage network belonging to the Danube River Basin. The Danube Basin in Croatia covers around 2/3 of the country's area with around 3/4 of the total Croatian population. The climate is also diverse, with variations of the continental climate in the Danube River Basin and transition and variations of the Mediterranean climate towards the south (Dalmatia). Precipitation patterns as the main input in the hydrological cycle are also very diverse. Total annual amounts of precipitation vary from less than $200 \mathrm{~mm} / \mathrm{year}$ in the east to more than $3500 \mathrm{~mm} / \mathrm{year}$ in the mountainous part of Gorski Kotar (hinterland of the port city of Rijeka). Diverse climate, geological and geomorphological features result in a variety of discharge regimes of rivers in Croatia (Čanjevac, 2013).

For the purposes of this research we have decided to use the most recent 20-year period from 1990 to 2009 as the time framework. Although we have also performed some tests for a limited number of stations for the 50-year period from 1960 to 2009, we have chosen the most recent 20 -year period in order to assess contemporary trends and to perform the analysis on as many stations and rivers as possible. We are aware that taking a 20 -year period for the trend analysis can lead to less reliable conclusions, but the limitations with data availability and gaps on many gauging stations in Croatia determined our study.

At the beginning of 2012, there were 448 gauging stations under the auspices of the Meteorological and Hydrological Service of Croatia. This research uses the mean monthly discharge data from 116 hydrological stations in Croatia. The main selection criterion is the length of time series without gaps. Through the selection and homogeneity testing we chose 53 stations on 39 rivers for the performance of statistical tests. 


\section{PREVIOUS RESEARCH}

The most significant research activity in the last 15 years refers to different aspects of change in minimum, average and maximum values of discharge on rivers in Croatia. For instance, research results have been published for the River Sava by O. Bonnaci and D. Oskoruš (2011), D. Trninić and T. Bošnjak (2009), K. Pandžić et al. (2009), O. Bonacci and I. Ljubenkov (2008), T. Šegota and A. Filipčić (2007); for the River Drava by O. Bonacci and D. Oskoruš (2010), and M. Gajić-Čapka and K. Cesarec (10); for the Rivers Lika and Gacka by O. Bonacci and I. Andrić (2008, 2009); for the rivers of the Kupa Basin by O. Bonacci and I. Andrić (2010), and K. Žganec (2011); while the research results of discharge changes for the Dalmatian rivers Ombla and Cetina have been published by O. Bonacci (1995) and O. Bonacci and T. Roje-Bonacci (2001, 2003). According to their approach, the aforementioned pieces of research can roughly be grouped in two groups. The first group focuses primarily on describing the changes in discharge within the analysis of climate element changes, while the other group (Bonacci and co-authors) largely stresses the significance of the human impact on the river regime. In his studies, along with other hydrological methods, O. Bonacci uses the RAPS method (Rescaled Adjusted Partial Sums) for determining changes and trends in data series, particularly valuable for the visualisation of changes and the segmentation of long-term data series (Garbrecht and Fernandez, 1994).

For reasons of methodology and spatial correlation (mostly upstream countries), we also analyse the research results of Slovenian (Ulaga, 2002; Frantar, 2003; Frantar, 2005; Frantar, 2007; Brilly et al., 2007; Ulaga et al., 2008), Austrian (Fürst et al., 2008; Fürst et al., 2010), German (Bormann, 2010) and Hungarian (Belz et al., 2004) authors who have studied recent discharge changes in their respective countries and on rivers in the wider area of the Danube Basin. Due to the changes observed on rivers, which are linked to the changes in snowfall and snow cover duration, Swiss authors' research is also analysed (Birsan et al., 2005).

\section{METHODOLOGY}

The sources of uncertainty or inaccuracy in hydrological systems are numerous. The most important uncertainties are those related to hydrological data, since they are the basis of all research and decision-making. Being aware of those uncertainties is highly important if we want to interpret the changes in time and space. Data limitations and uncertainties will remain an important part of hydrology in the foreseeable future (Shaw et al., 2010). Therefore, we chose methods that have been used on multiple occasions and verified through relevant research worldwide and in Croatia. The Wilcoxon test was used for the homogeneity analysis while the Mann-Kendall test, considered appropriate because of its resistance to extreme values that often cause problems in trend analyses, was used for the significativity analysis of changes in discharge (Helsel and Hirsch, 1992; Kundzewicz, 2004; Kundzewicz and Robson, 2004). The Kendall-Theil (or Sen) method was used for the estimate of the mean annual change of the mean discharge in the observed period of time, and also in order to get a better picture considering extreme values (Helsel and Hirsch, 1992; Fürst et al., 2008).

\section{HOMOGENEITY OF DATA}

Prior to the statistical trend analysis, it was necessary to determine the homogeneity of data series. The existence of sudden changes or jumps in data, most frequently caused by the change in the location of the gauging station, modifications of the measurement instruments, building of dams, or sudden changes in watercourse profiles, was determined by testing the data series for homogeneity. The testing of homogeneity was done by means of different statistical tests, among 
Hrvatski geografski glasnik 77/1 (2015.)

Tab. 1 Basic information on the hydrological stations used for the trend analysis

Tab. 1. Osnovne informacije o hidrološkim stanicama upotrijebljenima u analizi trendova

\begin{tabular}{|c|c|c|c|c|}
\hline River/stream & Station & $\begin{array}{c}\text { Elevation of } \\
\text { "0" } \\
\text { (m a.s. 1.) }\end{array}$ & $\begin{array}{l}\text { Topographic } \\
\text { catchment area of } \\
\text { the station }\left(\mathrm{km}^{2}\right)\end{array}$ & $\begin{array}{l}\text { Average yearly } \\
\text { discharge in } \mathrm{m}^{3} / \mathrm{s} \\
(1990-2009)\end{array}$ \\
\hline Bednja & Tuhovec & 162,85 & 469,54 & 5,01 \\
\hline Bednja & Lepoglava & 147,35 & 546,98 & 1,35 \\
\hline Biđ & Vrpolje & 78,56 & 214 & 1,16 \\
\hline Bijela & Badljevina & 137,14 & 170 & 1,64 \\
\hline Bregana & Bregana Remont & 152,33 & 88,5 & 1,22 \\
\hline Cetina & Han & 296,63 & 836 & 49,49 \\
\hline Čabranka & Zamost II & 297,66 & 103 & 3,47 \\
\hline Česma & Čazma & 97,11 & 2406 & 14,54 \\
\hline Česma & Narta & 103,36 & 880,8 & 4,84 \\
\hline Donja Dobra & Stative Donje & 116,47 & 1008 & 33,87 \\
\hline Donja Mrežnica & Mrzlo Polje & 113,97 & 879 & 25,49 \\
\hline Drava & Botovo & 121,55 & 31.038 & 456,2 \\
\hline Drava & D.Miholjac C.S. & 88,57 & 37.142 & 496,95 \\
\hline Drava & Novo Virje skela & 108,87 & 31.803 & 469,85 \\
\hline Drava & Terezino Polje & 100,67 & 33.916 & 480,05 \\
\hline Gliboki & Mlačine & 144,45 & 84 & 0,56 \\
\hline Gornja Dobra & Luke & 353,67 & 162 & 6,47 \\
\hline Gornja Dobra & Turkovići & 323,72 & 298 & 10,54 \\
\hline Gradna & Samobor & 150,53 & 38,1 & 0,59 \\
\hline Ilova & V.Vukovje & 98,65 & 995 & 7,3 \\
\hline Jadro & Majdan & 13,46 & - & 7,14 \\
\hline Korana & Slunj uzv. & 212,17 & 944 & 8,8 \\
\hline Krapina & Kupljenovo & 128,88 & 1150 & 10,12 \\
\hline Krapinčica & Zabok & 141,48 & 192,4 & 1,83 \\
\hline Krka & Skradinski buk g. & 45,4 & 2.103 & 47,39 \\
\hline Kupa & Hrvatsko & 285,21 & 370 & 18,96 \\
\hline Kupa & Kamanje & 123,83 & 2047 & 65,41 \\
\hline Kupa & Kupari & 304,43 & 208 & 12,95 \\
\hline Kupčina & Strmac & 155,14 & 125 & 1,91 \\
\hline Kupica & Brod na Kupi & 221,43 & 251 & 11,92 \\
\hline Kutina & Kutina & 96,34 & 55,3 & 0,34 \\
\hline Londža & Pleternica & 114,33 & 483 & 1,7 \\
\hline Lonja & Lonjica most & 103,77 & 326 & 1,66 \\
\hline Mirna & Buzet & 42,07 & 127 & 1,92 \\
\hline Mirna & Portonski most & 1,68 & 483 & 5,86 \\
\hline Mura & Goričan & 138,59 & 13.148 & 167,55 \\
\hline
\end{tabular}


Tab. 1 continuation

Tab. 1. u nastavku

\begin{tabular}{|l|l|c|c|c|}
\hline \multicolumn{1}{|c|}{ River/stream } & \multicolumn{1}{|c|}{ Station } & $\begin{array}{c}\text { Elevation of } \\
\text { "0" } \\
\text { (m a. s. 1.) }\end{array}$ & $\begin{array}{c}\text { Topographic } \\
\text { catchment area of } \\
\text { the station }\left(\mathrm{km}^{2}\right)\end{array}$ & $\begin{array}{c}\text { Average yearly } \\
\text { discharge in } \mathrm{m}^{3 / \mathrm{s}} \\
(1990-2009)\end{array}$ \\
\hline Mura & M.Središče & 156,29 & 10.891 & 159,87 \\
\hline Novčica & Lički Novi & 554,32 & - & 2,32 \\
\hline Orljava & Pleternica most & 113,76 & 437,6 & 4,99 \\
\hline Orljava & Požega & 143,97 & 59,7 & 3,29 \\
\hline Pazinčica & Dubravica & 249,59 & 19 & 0,72 \\
\hline Rječina & Martinovo selo & 270,38 & 12.316 & 6,64 \\
\hline Sava & Podsused žičara & 119,13 & 12.730 & 265,65 \\
\hline Sava & Rugvica & 95,61 & 12.450 & 277,47 \\
\hline Sava & Zagreb & 112,26 & 62.891 & 274,23 \\
\hline Sava & Županja & 76,28 & 225,5 & $1.027,1$ \\
\hline Sunja & Sunja & 99,14 & 455 & 2,73 \\
\hline Sutla & Zelenjak & 162,46 & 30,6 & 6,01 \\
\hline Toplica & Daruvar & 151,59 & 105,13 & 0,31 \\
\hline Trnava & Jendrašiček & 150,9 & 11 & 0,31 \\
\hline Vitunjčica & Brestovac & 335,82 & - & 3,21 \\
\hline Vrljika & Kamenmost & 259,69 & 169,95 & 7,06 \\
\hline Vučica & Orahovica & & & 0,48 \\
\hline
\end{tabular}

Source: Meteorological and Hydrological Service of the Republic of Croatia Izvor: Državni hidrometeorološki zavod Republike Hrvatske

which the Wilcoxon test is one of the most frequently used (Žugaj, 2000; Prohaska and Ristić, 2002; Biondić, 2005; Reimann et al., 2008; Walford, 2011). The Wilcoxon non-parametric test is based on comparison and summing up of the ranks of two data series (s1 and s2) and the calculation of the standard aberration of the modified series (s2) (Žugaj, 2000). When applying the test, the data series that needs to be checked is divided in two parts (s1 and s2) according to the year when the potential cause of non-homogeneity appeared. If the year when potential changes appeared is unknown, the time series is usually divided into two equal parts (Prohaska and Ristić, 2002). The series (s1 and s2) have to be subsequent and neither can be shorter than seven years (Žugaj, 2000). The critical region of the null hypothesis (that there are no significant changes in data) is covered by the lower and upper levels of confidence of $\alpha= \pm 5 \%$ (Žugaj, 2000; Biondić, 2005). Analogously, in this case, if the value of the probability coefficient $\mathrm{p}$ was less than 0,05 , the starting hypothesis that the series was homogenous was rejected with a $95 \%$ probability and the conclusion, according to this statistical test, was that the series was not homogenous.

At the beginning of this research, we included 116 gauging stations. After the analysis and homogeneity testing of 157 data series (in some cases, after non-homogeneity had been determined on the entire series, the shorter part of the series was analysed), 79 series were determined as homogeneous. Finally, 53 out of the 79 series, i.e. stations with homogenous and sufficiently long data series, were appropriate for trend analysis (Tab. 1, Fig. 1). 


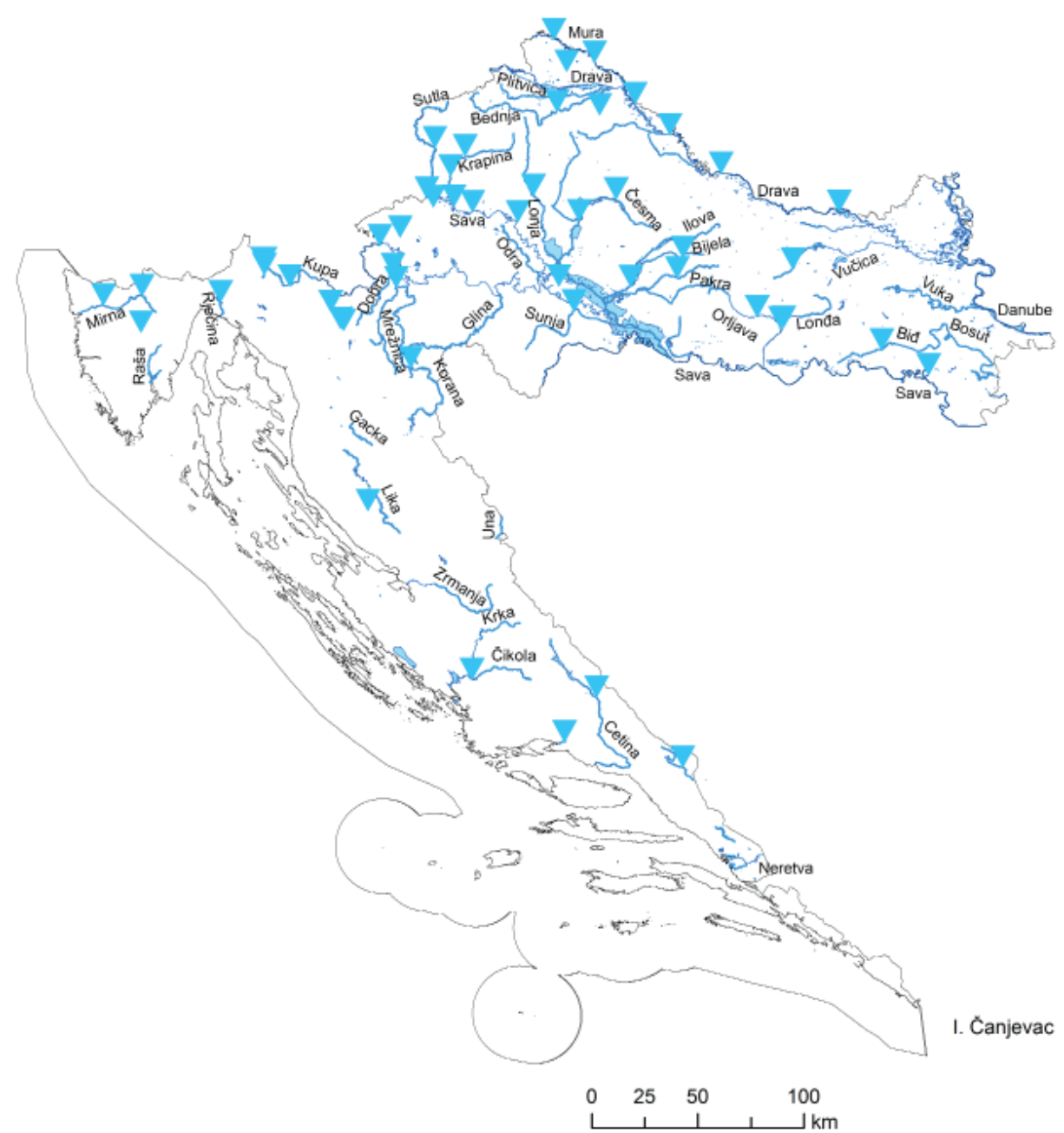

Fig. 1 Hydrological stations used for the trend analysis

Sl. 1. Hidrološke stanice upotrijebljene u analizi trendova 


\section{TREND ANALYSIS}

The analysis was continued by calculating the linear trend equations in the period from 1990 to 2009 for 53 stations on the total of 39 rivers in Croatia. The analysis covered all the important Croatian rivers with determined data homogeneity.

A descending trend in the annual discharge was found at 29 stations and it was statistically significant on six of them. An ascending trend was calculated at 24 stations, out of which two stations showed a statistically significant trend. The significativity of the aforementioned trends was analysed by the Seasonal Mann-Kendall test. It is necessary to stress that these are the analysis results of the mean annual value data series and that a more thorough analysis and a possible determination of general causes of change required a trimestral, i.e. seasonal analysis, approach.

A more detailed analysis of the values of mean discharge changes on a yearly and seasonal basis in the period analysed last (1990-2009) was done in order to detect spatial differences and critical periods in a year when the changes in discharge on Croatian rivers are the most pronounced. By doing so, we drew closer to determining the key mechanisms causing the changes. The Kendall-Theil test proved to be successful when determining the average values of change within a particular period because it takes the period median into consideration when determining the values of change, instead of, for instance, the starting point value or some other mean value (Fürst et al., 2008). This allowed us to obtain more reliable data because extreme values did not affect the results as much. The statistical significativity was calculated for each change on the lower and upper level of confidence of $\alpha= \pm 5 \%$. The testing was done at the same 53 stations on 39 rivers in Croatia as in the case of linear trends.

\section{RESULTS \\ Results on an annual basis}

On an annual basis, in the period from 1990 to 2009, a decrease in average discharge was detected at 31 stations, and it was statistically significant at four out of the 31 stations (Fig. 2).

The decrease ranges from the minimal $-0.02 \%$ (Mura) to over $-2.3 \%$ (Gliboki) a year. A pronounced decrease, statistically significant at the same time, was detected on smaller streams of lowland Croatia (Gliboki, Orljava and Česma). An average increase in discharge on an annual basis was detected at 22 stations with no results being statistically significant. The largest increase in all Croatia (1.14\% annually) was found on the Gornja Dobra (the Turkovići station).

The next step was the analysis of the results for the basins. The Drava Basin was fully characterised by a decrease in discharge values. The values at the stations on the Drava and Mura actually indicated stagnation or absence of a marked trend of discharge change in the twenty-year period. The Bednja, Gliboki and Vučica streams, on the other hand, had a more marked decline in discharge. At the Mlačine gauging station (Gliboki) it was $-2.34 \%$ annually, which was also the largest decrease of all the analysed stations in Croatia. The data for the Sava River in Croatia showed a very small increase on an annual basis at the stations around Zagreb in the period from 1990 to 2009, whereas a small decrease was detected in the eastern part of Croatia (the Županja station). The Sava Basin showed mixed results. The right-hand side of the basin (the Kupa Basin) mostly showed a more or less marked increase in discharge on a yearly level, while a decrease was usually detected on the left-hand side of the basin. The River (Gornja) Dobra, at the Turkovići station, had the most pronounced average increase in discharge $(1.14 \%)$, whereas the most pronounced (and statistically significant) decrease was detected on the Rivers Česma (both stations) and Orljava (the Pleternica Most station). The Istrian Rivers Mirna and Pazinčica had a decrease in discharge, as did the Novčica River in Lika, while Dalmatian rivers showed no significant changes. 


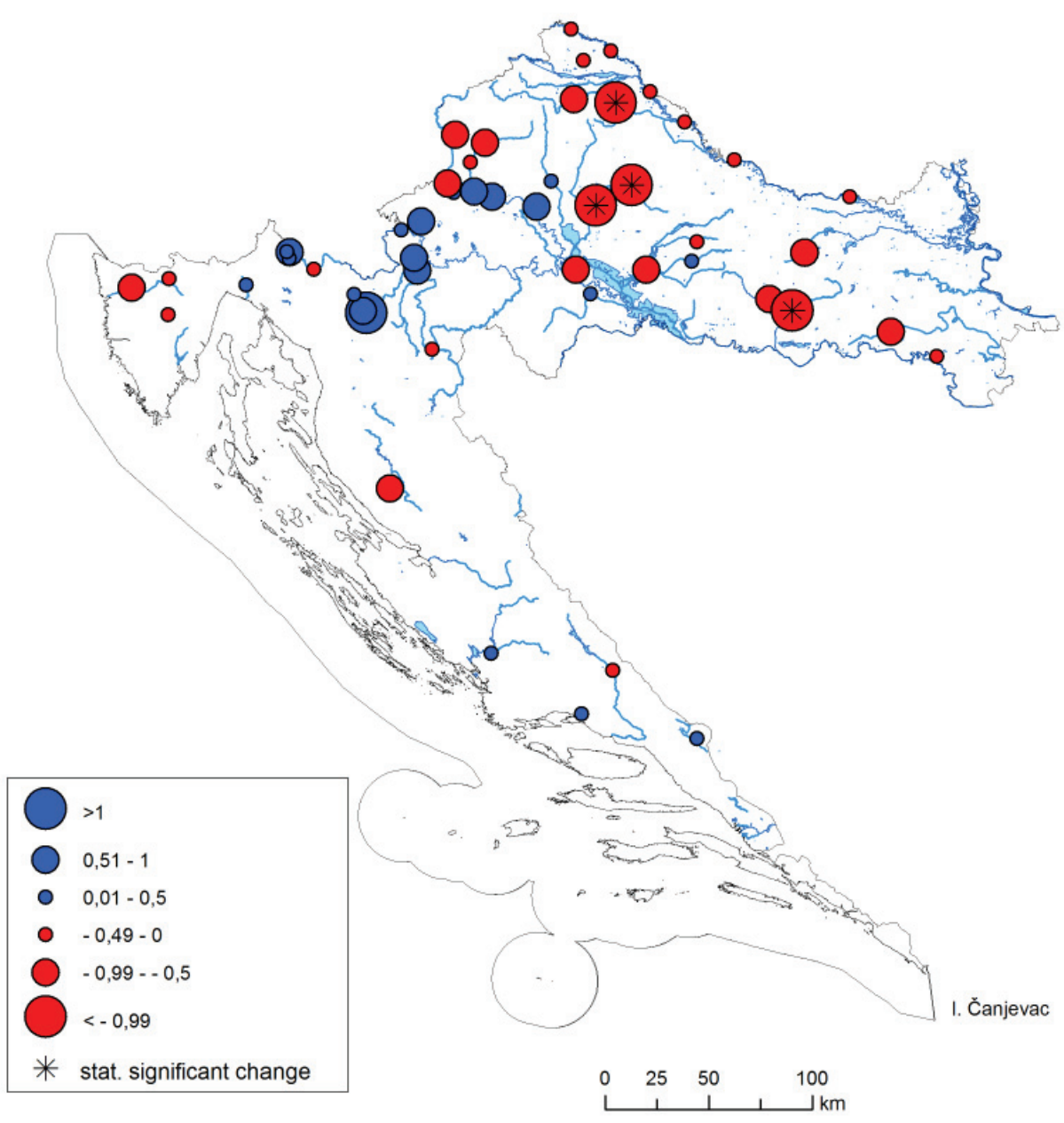

Fig. 2 Values of mean yearly discharge change (\% in comparison with the median) in the 1990-2009 period. Sl. 2. Vrijednosti srednje godišnje promjene protoka (\% u odnosu na medijan razdoblja) od 1990. do 2009. 


\section{Results on a seasonal basis}

A number of studies have shown that trends, i.e. changes in discharge, are more marked and easier to detect on the level of particular months or seasons (Fürst et al., 2008; Arnell, 1992; Arnell and Reynard, 1996; Baggaley et al., 2009...). This study has shown the same.

\section{Spring}

In the seasonal analysis, spring was defined as the March-April-May trimester. The observed results were more marked than on the annual level. A great majority of stations showed an average annual increase in discharge (Fig. 3).

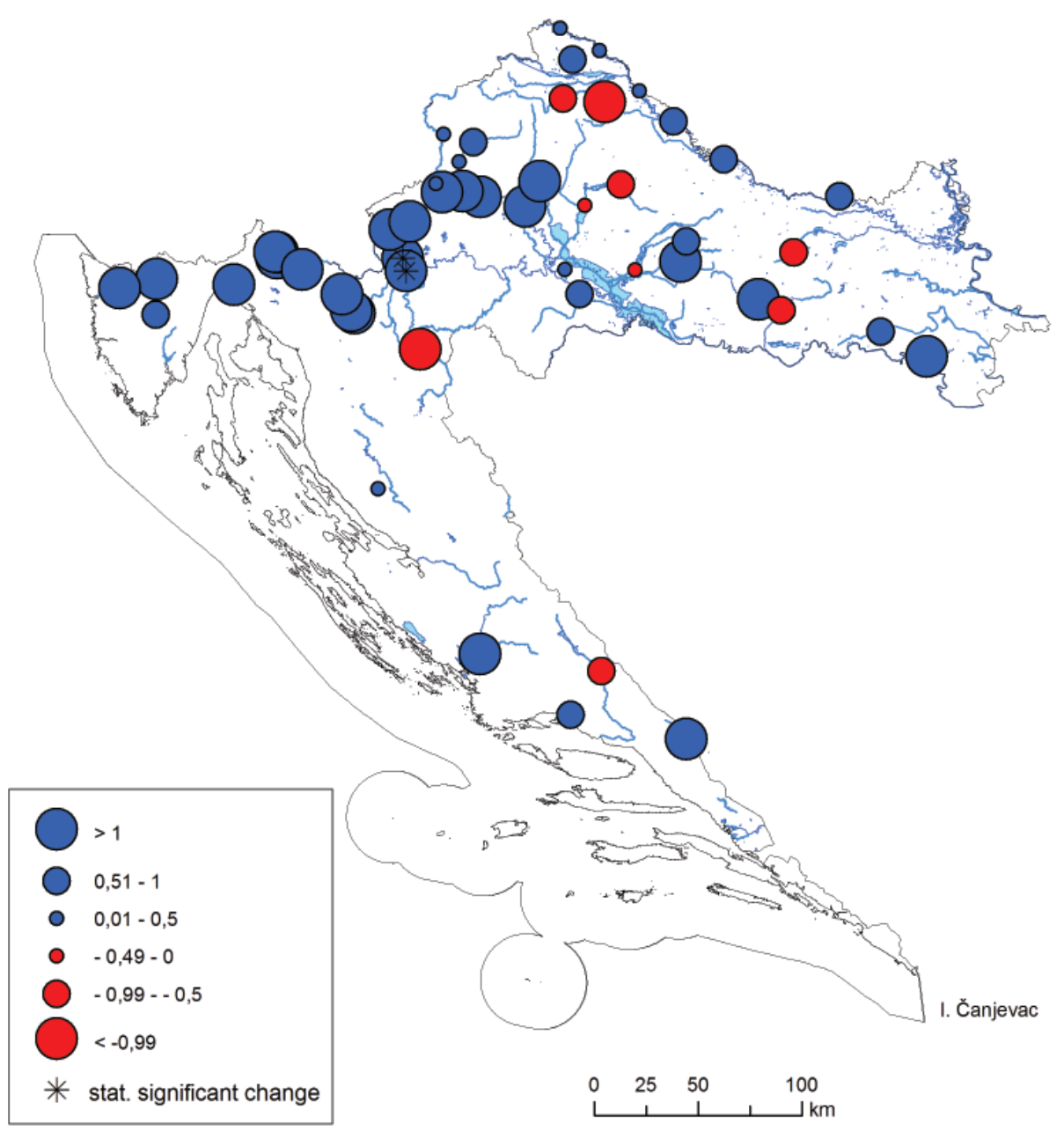

Fig. 3 Values of mean discharge change in spring (\% in comparison with the median) in the 1990-2009 period

Sl. 3. Vrijednosti srednje godišnje promjene protoka u proljeće (\% u odnosu na medijan razdoblja) od 1990. do 2009. 
The increase was the most pronounced in the Kupa Basin where (Donja) Dobra and (Donja) Mrežnica exhibited a statistically significant increase in discharge of more than $2 \%$ annually on average within the observed timespan. The Drava Basin showed the least pronounced increase. Within the observed period, only 10 stations exhibited a decrease in the spring months. These were once again mainly smaller streams of lowland Croatia and the Rivers Korana and Cetina. When comparing all the months of the year, March showed the most marked positive average change of discharge (Fig. 4). A decrease in discharge in March was detected for two rivers only (the Korana and Cetina), while others largely showed a significant average increase, which was also statistically significant at 23 stations. The largest increase was detected at the Dubravica on the Pazinčica River (5, 72\%) and Turkovići stations on the Gornja Dobra River (5.6\%). In the case of the Rivers Mura and Drava the increase was the least pronounced.

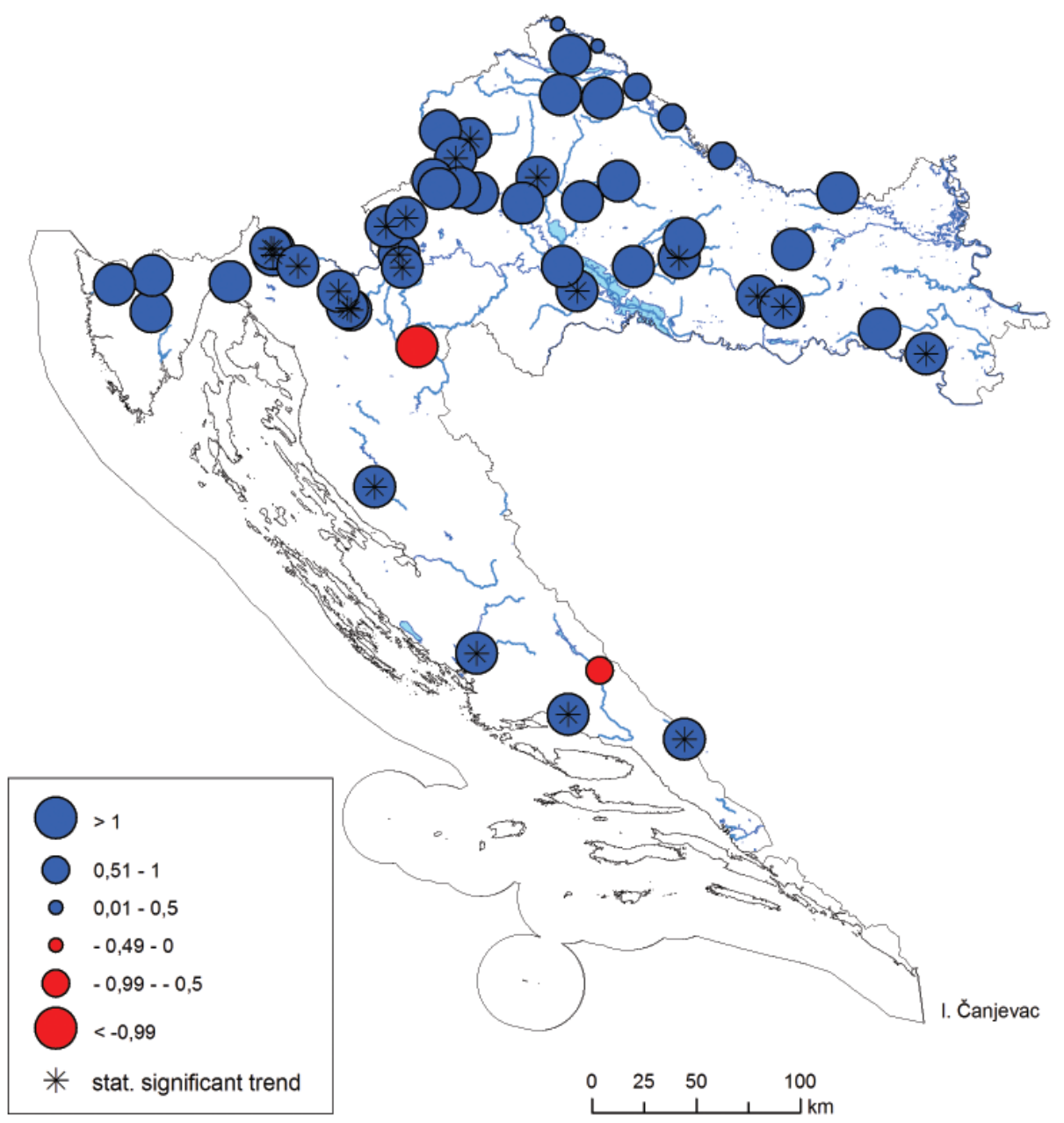

Fig. 4 Values of mean discharge change in March (\% in comparison with the median) in the 1990-2009 period.

Sl. 4. Vrijednosti srednje godišnje promjene protoka u ožujku (\% u odnosu na medijan razdoblja) od 1990. do 2009. 


\section{Summer}

The results for the summer trimester (June, July and August) exhibited more pronounced regional differences (Fig. 5). An increase in discharge was detected on the rivers of north Croatia (the Drava Basin and parts of the Sava Basin) and south Croatia (the Rivers Krka, Cetina and Vrljika). However, this increase was statistically significant at only one station (Kupčina-Strmac). There was a marked decrease on the rivers of east and west Croatia, which was statistically significant at five stations.

The River Kupčina had the most pronounced discharge increase with the summer average at over $2 \%$, while the increase was again the least pronounced on the Rivers Drava and Mura. On the other hand, the decrease was marked on smaller karst rivers (the Kupa and Lika Basin), in

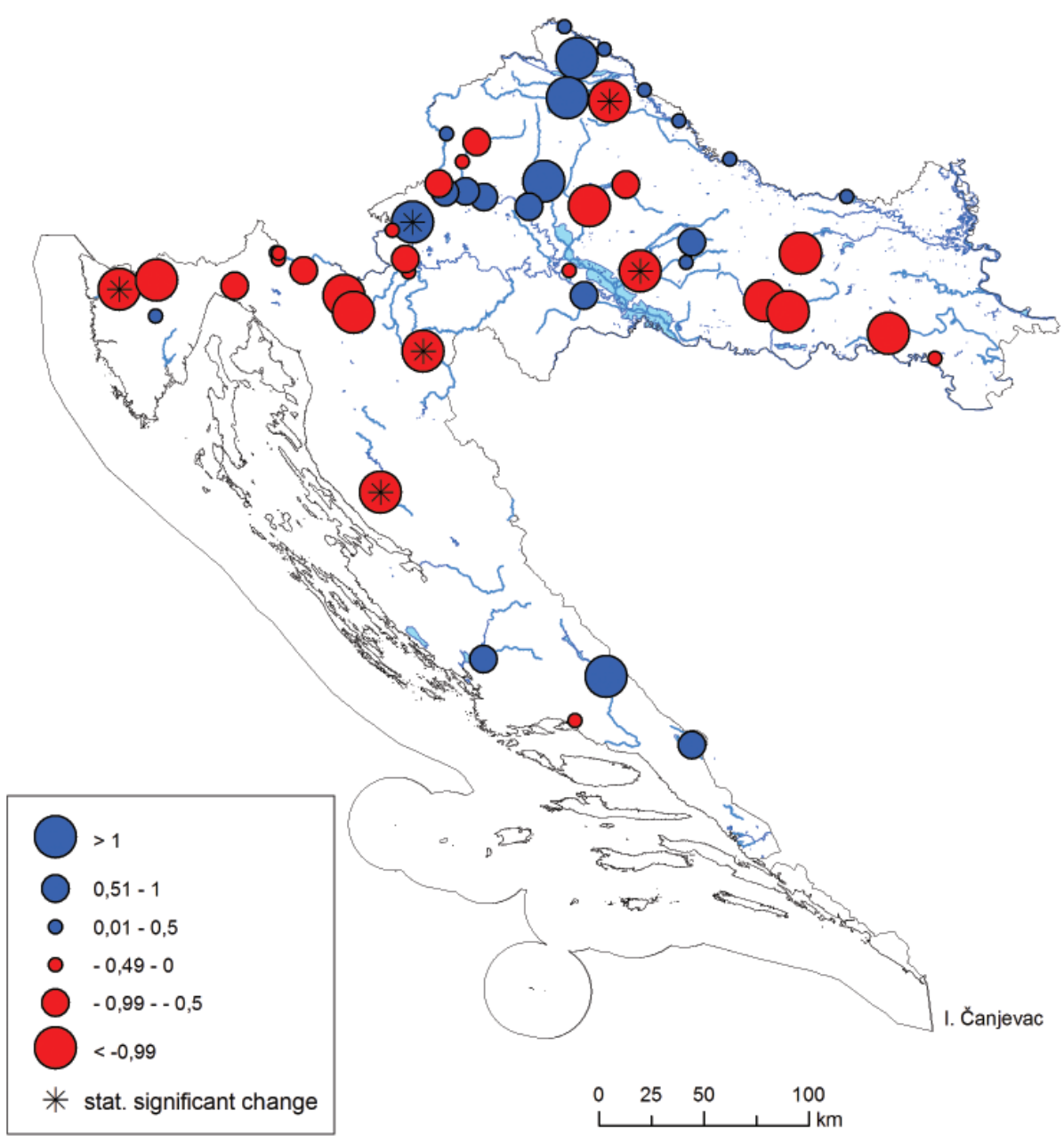

Fig. 5 Values of mean discharge change in summer (\% in comparison with the median) in the 1990-2009 period. Sl. 5. Vrijednosti srednje godišnje promjene protoka ljeti (\% u odnosu na medijan razdoblja) od 1990. do 2009. 
Istria (the Mirna) and in smaller basins of lowland Croatia. The Gliboki and Korana had the most marked decrease of more than $-2.5 \%$ annually. There were three more stations with a statistically significant decrease: Ilova - Veliko Vukovje, Mirna - Portonski most and Novčica - Lički Novi.

\section{Autumn}

The values of change in the mean monthly discharge for autumn months (September, October and November) showed a decrease at nearly all the gauging stations (Fig. 6). These were usually values smaller than $-1 \%$ per year.

The decrease was statistically significant at ten stations. The smallest decrease was again detected on the Rivers Drava and Mura. On the other hand, it was the most pronounced on the

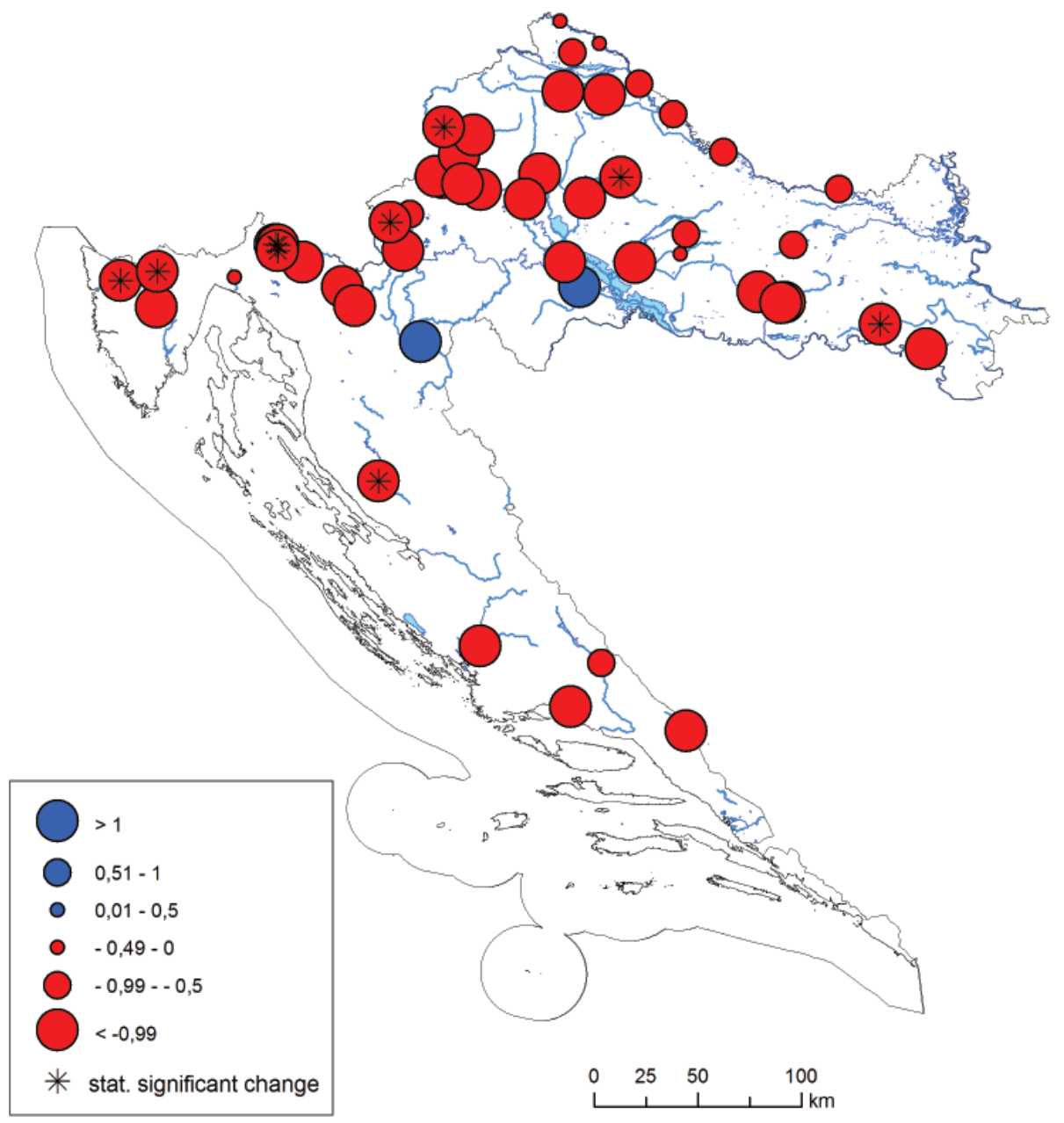

Fig. 6 Values of mean discharge change in autumn (\% in comparison with the median) in the 1990-2009 period. Sl. 6. Vrijednosti srednje godišnje promjene protoka ujesen (\% u odnosu na medijan razdoblja) od 1990. do 2009. 
Istrian River Mirna, the Rivers Česma and Sutla, the Novčica in Lika, the Biđ in Slavonia and in the Kupa Basin where the negative change values at some stations were lower than $-3.5 \%$ annually. The only rivers showing an increase in discharge in the autumn months in the observed period were the Sunja (Sunja station) and Korana (Slunj station). November was the month with the most marked decrease in mean discharge value in the entire particular year in the observed period (Fig. 7). The decrease was even more marked than the autumn months' average and it was statistically significant at half of the stations (23). It was the most marked on smaller streams of lowland Croatia (Kutina, Česma, Orljava) and on Istrian rivers where it exceeded $-3.5 \%$. Once again, positive values of change were detected only on the Rivers Sunja and Korana.

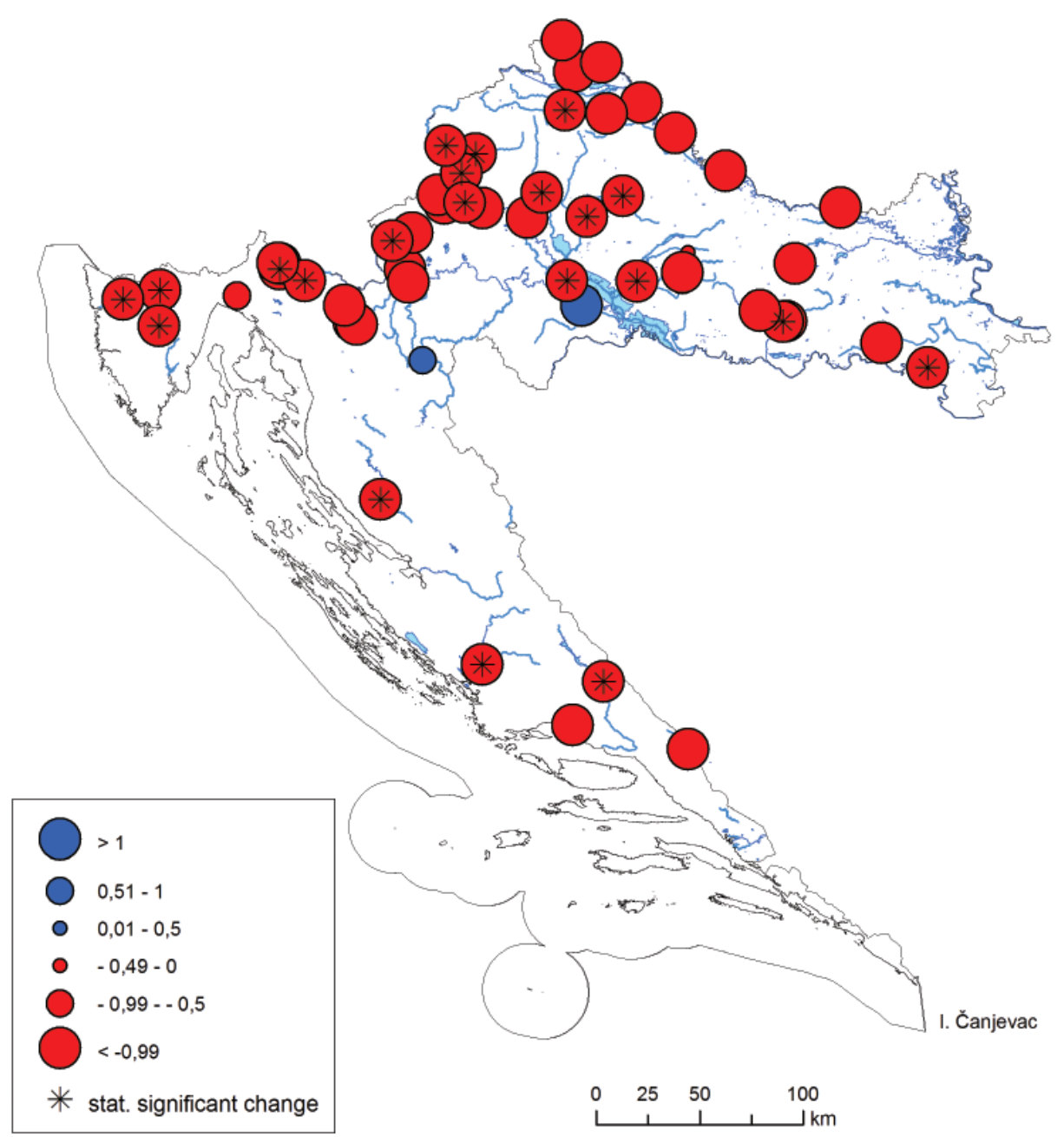

Fig. 7 Values of mean discharge change in November (\% in comparison with the median) in the 1990-2009 period.

Sl. 7. Vrijednosti srednje godišnje promjene protoka u studenome (\% u odnosu na medijan razdoblja) od 1990. do 2009. 


\section{Winter}

As in the case of the summer trimester, the results for the winter trimester (December, January and February) also showed more pronounced regional differences (Fig. 8). The largest increase was detected on the rivers of west Croatia - the rivers of Istria and the Kupa Basin as well as most Dalmatian rivers (with the exception of the Cetina River). The increase was statistically significant only on the Gornja Dobra (the Turkovići station).

On the other hand, a decrease in mean discharge value was detected on most rivers of north and east Croatia. It was equally marked on larger and smaller rivers but statistically significant only in the case of two smaller lowland streams (the Gliboki and Trnava). The change in discharge value in the winter months was normally higher or lower than $+/-1 \%$.

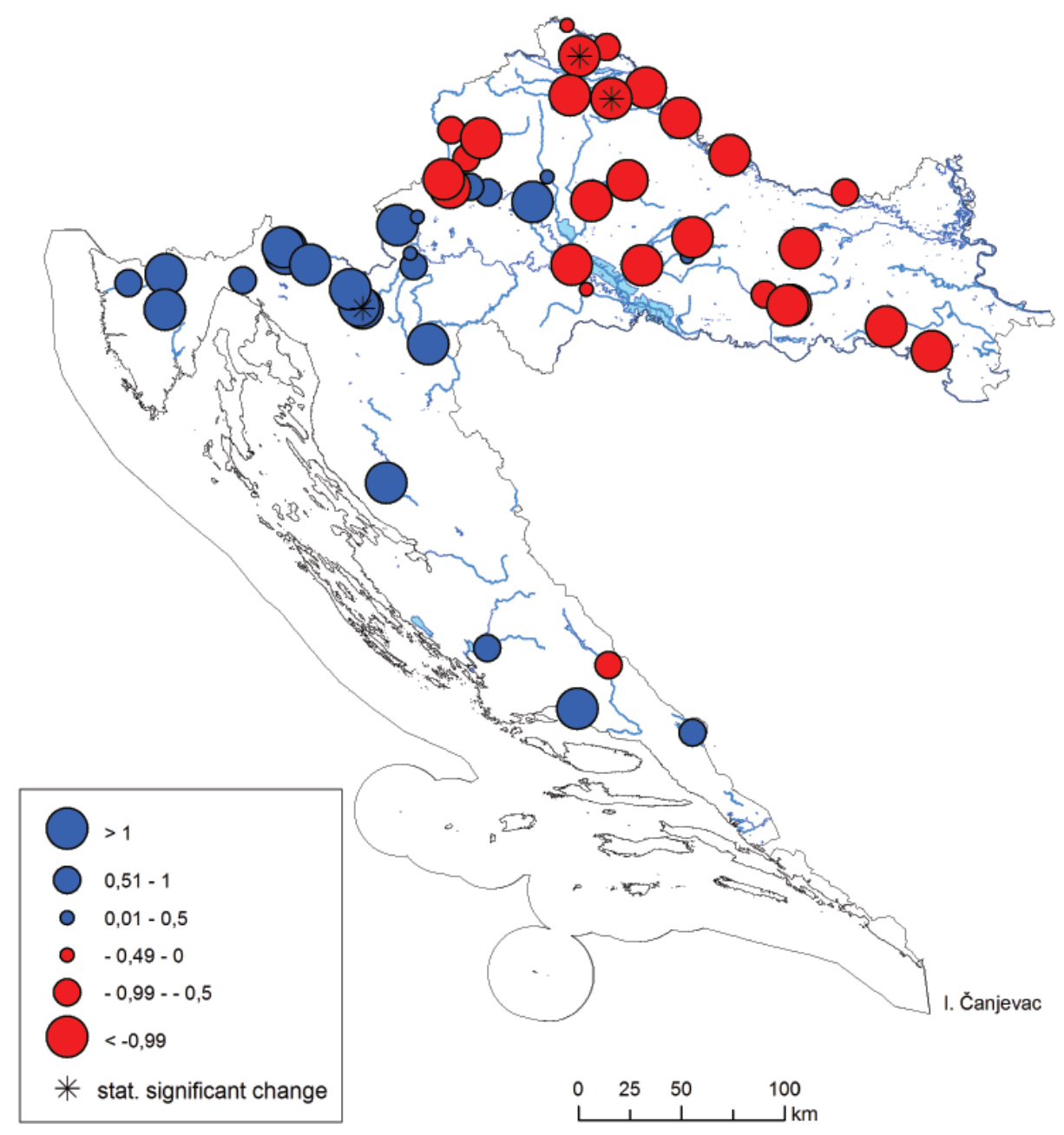

Fig. 8 Values of mean discharge change in winter (\% in comparison with the median) in the 1990-2009 period. Sl. 8. Vrijednosti srednje godišnje promjene protoka zimi (\% u odnosu na medijan razdoblja) od 1990. do 2009. 


\section{DISCUSSION}

The trend analysis for the last twenty-year period reflects a complex picture and confirms the hypothesis about uncertainties in making conclusions and generalising results. Little over a half of the 53 analysed stations had a negative trend, and on most of them the trend was not statistically significant. More significant decreases were seen in the case of smaller lowland streams of central and east Croatia. This is probably related to the sensitivity of smaller basins to climatic change or oscillation. Over the last century, lowland Croatia has generally shown a mild increase in mean annual air temperature, a decrease in the precipitation quantity and humidity of soil, and an increase in potential evapotranspiration, with a statistically significant trend since 1987 (Zaninović and Gajić-Čapka, 1999). Furthermore, the precipitation variability in continental Croatia increases towards the East (Maradin, 2011; Maradin, 2012). Larger rivers of the continental part (the Sava, Drava and Mura) exhibited a small decrease or increase primarily as a consequence of changing conditions in the upstream countries, i.e. Slovenia (Frantar, 2003; Frantar, 2005; Frantar, 2007) and Austria (Fürst et al., 2008; Fürst et al., 2010). In these cases, the basin size and intensive human interventions make the causal relationship of climatic elements change and runoff less clear, although observed signals are the same. A great number of hydroelectric power plants have been constructed on all three rivers, especially on the Drava (23) and Mura (26). Given that their construction has further stabilised the already steady runoff regime, the consequences of climatic changes are more difficult to detect.

A more marked increase in annual discharges was detected only in the Kupa Basin. This is primarily the result of the trend of climatic elements change, i.e. the average annual temperature increase, decrease in snow-cover duration and the number of days with solid precipitation in the area (Gajić-Čapka, 2011). Further seasonal analysis confirmed such a conclusion. Interestingly, varied trend combinations (decrease - decrease and decrease - increase) were detected at the stations which were analysed in both the 50 and the 20 -year period. As direct human interventions in the hydrological cycle in Croatia over the last 20 years have been relatively small, the results speak in favour of oscillations of climatic elements (precipitation in particular) and their spatial and temporal characteristics (annual or decadal). A more detailed analysis showed indicative and clearer change, primarily on the seasonal level in the period from 1990 to 2009.

The seasonal results for the period from 1990 to 2009 support conclusions on the annual level. The marked trend of increased discharge in the spring, especially on the rivers fed by snowmelt, as well as the increase in the mean annual temperature, suggest that, due to warmer winters with less snow, there is a change in the ratio of solid to liquid precipitation in favour of rainfall. This reduces the retardation effect of the colder months on water resources, the amount of runoff gets distributed and the spring maxima shift towards the winter months. Such trends and processes are consistent with those in the Alps (Fürst et al., 2010; Birsan et al., 2005). In addition, the most marked positive trend of all the months in the year was detected in March. In the case of the Mura and Drava the positive trend was somewhat less pronounced.

A decrease in discharge in the summer months was the most pronounced in east and west Croatia and in the mountainous part of Croatia. Several Dalmatian rivers (the Cetina, Krka and Vrljika) exhibited interesting results with a discharge increase in the summer months, mainly due to the August increase, although that increase was not statistically significant. At first glance, this is partly opposite to the results of previous studies, which indicated a temperature increase and a decrease in the value of surface runoff in the coastal area of Dalmatia, in particular since the beginning of the 1990s (Gajić-Čapka and Zaninović, 2006). However, precipitation trends were not as pronounced. In addition, the Cetina and Vrljika Rivers, for instance, are fed from the Dinaric mountains and hinterland. This has to be taken into consideration, since the Hvar meteorological station, used in the mentioned research, is not representative for those rivers. 
The nearly uniform trend of discharge decrease in the autumn months is the consequence of the increase in summer temperatures and evapotranspiration values and the reduced amount of precipitation. Such a decrease is also the direct consequence of the reduced amount of precipitation in the autumn. This is particularly noticeable in November, the month with the most pronounced decrease in discharge values at almost all the observed stations. Such November change in discharge is related to the fact that October is the month with a pronounced decrease in the amount of precipitation and its increased variability (Maradin, 2011). At the same time, autumn is the season of the highest precipitation variability with values of over $33 \%$ in eastern Croatia (Maradin, 2011). The overall trend of drying in summer and autumn months noticed in the eastern part of Croatia is consistent with the results for eastern (dryer) parts of Austria (Fürst et al., 2008; Fürst et al., 2010). Winter month trends showed an increase in discharge in the part of Croatia with the maritime pluviometric regime (Mountainous Croatia, Istria, Dalmatia) on the one hand, and on the other, mainly a decrease in the part of Croatia with the continental pluviometric regime (with the exception of the upper course of the Sava River).

The World Meteorological Organization projections state that the decrease in discharge in the area of south and southeast Europe by the year 2070 will be up to $36 \%$ (Trninić and Bošnjak, 2009). Such projections are based on the climate models which take further increase in average annual temperature on Earth as a starting parameter, due to the increase of greenhouse gases. If the trends shown in this study continue, we expect that the aforementioned decrease will not equally affect all the rivers in Croatia. It is more likely that some rivers will show an increase both on a monthly and annual level. The projections of a further decrease in the snowcover duration and thickness in the Alpine area in the 21st century have to be taken into consideration as well (Steiger, 2010). The intensity of change for relatively lower altitudes (from 600 to $1300 \mathrm{~m}$ ) is particularly stressed. More certain predictions of the overall change in climate elements and their consequences on the river discharge regimes will require modelling on the basin level. This is made difficult due to the inadequate scale of climate models and the non-existence of several relevant data series for all the physical geographical features of a basin.

\section{CONCLUSION}

Over a half of the 53 analysed stations had a negative trend of annual discharge in the 19902009 period, but it was not statistically significant at most of those stations. More pronounced decreases were observed on smaller lowland streams of central and east Croatia. This is related to the sensitivity of smaller basins to climate change or oscillations. Larger rivers of the continental part (the Sava, Drava and Mura) exhibited a smaller decrease or increase primarily as a consequence of modified conditions in the upstream countries. In these cases, the basin size and intensive human interventions complicate causal relationships of climate elements and runoff. A more marked increase in annual discharges was observed only in the Kupa Basin. A detailed analysis showed indicative and more uniform signals of change, primarily on the seasonal level in the period between 1990 and 2009. Given the period of analysis and the significance of results, we handle conclusions with care but they can be used as an indicator of changing conditions on rivers in Croatia. Smaller scale investigations should follow.

There are several possible consequences for Humankind and the whole ecosystem that the mentioned changes bring about. Lower summer discharges carry the danger of elevated concentration of pollutants in watercourses as well as the reduced amount of water available for water supply and other human activities. This problem is particularly dangerous for the coastal part of Croatia, where the needs for water are highest in the summer months when the number of users of space and water resources increases exponentially due to the arrival of tourists. The decreased discharges and 
increased concentrations of pollutants together with the rise of water temperatures also endanger and change river ecosystems, affecting plant and animal species. The increased spring discharges, on the other hand, along with the sudden melting of snow, can increase the risk of flooding in the late winter months and early spring months. These changes in discharge regimes should definitely be taken into account when managing water resources in all sizes of basins.

\section{REFERENCES}

Arnell N. W., 1992: Factors controlling the effects of climate change on river flow regimes in a humid temporal environment, Journal of Hydrology 132, 321-342.

Arnell N. W., Reynard N. S., 1996: The effects of climate change due to global warming on river flows in Great Britain, Journal of Hydrology 18, 397-424.

Baggaley N. J., Langan S. J., Futter M. N., Potts J. M., Dunn S. M., 2009: Long-term trends in hydro-climatology of a major Scottish mountain river, Science of the Total Environment 407, 4633-4641.

Belz J. U., Goda L., Buzás Z., Domokos M., Engel H., Weber J., 2004: Flow Regime of River Danube and its Catchment - an update of Chapter II of the Danube Monograph,

Biondić D., 2005: Flood Waves in Croatian Watercourses of the Black Sea River Basin, Doctoral thesis, University of Zagreb, Faculty of Civil Engeneering, Zagreb (in Croatian).

Birsan M.-V., Molnar P., Burlando P., Pfaundler M., 2005: Streamflow trends in Switzerland, Journal of Hydrology 314, 312-329.

Bonacci O., 1995: Groundwater behavior in karst regions: Example of the Ombla spring (Croatia), Journal of Hydrology 165 (1-4), 113-134.

Bonacci O., Andrić I., 2008: Sinking karst rivers hydrology: case of the Lika and Gacka (Croatia), Acta Carsologica 37 (2), 185-196.

Bonacci O., Andrić I., 2009: Joint hydrological analysis of the Lika and Gacka Rivers, Hrvatske vode 17 (67), 1-12 (in Croatian).

Bonacci O., Andrić I., 2010: Impact of an inter-basin water transfer and reservoir operation on a karst open s treamflow hydrological regime: an example from the Dinaric karst (Croatia), Hydrological processes 24 (26), 3852-3863. DOI: 10.1002/hyp.7817.

Bonacci O., Ljubenkov I., 2008: Changes in flow conveyance and implication for flood protection, Sava River, Zagreb, Hydrological Processes 22 (8), 1189-1196. DOI: 10.1002/hyp.6688.

Bonacci O., Oskoruš D., 2010: The changes of the lower Drava River water level, discharge and suspended sediment regime, Environmental Earth Sciences 59 (8), 1661-1670.

Bonacci O., Oskoruš D., 2011: Hydrological analyses of Zagreb town flood by the Sava River in recent conditions, Hrvatske vode 19 (75), 13-24 (in Croatian).

Bonacci O., Roje-Bonacci T., 2001: Man's influence on the hydrological regime of the karst river Cetina, Hrvatske vode 9 (37), 395-408 (in Croatian).

Bonacci O., Roje-Bonacci T., 2003: The influence of hydroelectrical development on the flow regime of the karstic river Cetina, Hydrological Processes 17 (1), 1-15. DOI: 10.1002/hyp.1190.

Bormann H., 2010: Runoff regime changes in German rivers due to climate change, Erdkunde 64 (3), 257-279.

Brilly M., Horvat A., Matthews D., Šraj M., 2007: Climate change impact on mean annual river flows, in Proceedings of the Third International Conference on Climate and Water, Helsinki, Finland, 82-87.

Chiew F. H. S., McMahon T. A., 1996: Trends in Historical Streamflow Records, in Regional Hydrological Response to Climate Change, Jones JAA, Liu C, Woo M-K, Kung H-T (eds), Kluwer Academic Publishers, The Netherlands, 63-68.

Čanjevac I., 2013: Typology of Discharge Regimes of Rivers in Croatia, Croatian Geographical Bulletin 75 (1), 23-42. 
Frantar P., 2003: Pretočni režimi na reki Savi in njihove spremembe med odbodjem 1961-90 in 1991-2000, 14. Mišičev vodarski dan - conference proceedings, 133-141 (in Slovenian).

Frantar P., 2005: River Flow Regimes of Slovene Rivers and Their Fluctuation, Ujma 19, 145-153 (in Slovenian).

Frantar P., 2007: Geographical overview of water balance of Slovenia 1971-2000 by main river basins, Acta geographica Slovenica 47 (1), 25-45.

Fürst J., Kling H., Nachtnebel H.P., Hörhan T., 2008: Trends in hydrologischen Variablen und in der Wasser bilanz Österreichs, in Auswirkungen des Klimawandels auf die österreichische Wasserwirtschaft, Nachtnebel H.P. (ed.), Bundesministerium für Land- und Forstwirtschaft, Umwelt und Wasserwirtschaft, Vienna, Austria, 105-115.

Fürst J., Kling H., Nachtnebel H.P., Hörhan T., 2010: Beobachtete Veränderungen in der Wasserbilanz Österreichs, in Auswirkungen des Klimawandels auf Hydrologie und Wasserwirtschaft in Österreich - Präsentation der aktuellen Studien, Nachtnebel, H.P. (ed.), Bundesministerium für Land- und Forstwirtschaft, Umwelt und Wasserwirtschaft, Vienna, Austria, 101-114.

Gajić-Čapka M., 2011: Snow climate baseline conditions and trends in Croatia relevant to winter tourism, Theoretical and Applied Climatology 105, 181-191.

Gajić-Čapka M., Cesarec K., 2010: Trend and variability in discharge and climate variables in the Croatian lower Drava river basin, Hrvatske vode 18 (71), 19-30 (in Croatian).

Gajić-Čapka M., Zaninović K., 2006: Long-Term Trends in Temperature, Precipitation and Runoff at the Croatian Eastern Adriatic Coast, in Conference on water observation and information system for decision suport BALWOIS 2006, Morell M (ed.), Ohrid, Macedonia.

Garbrecht J., Fernandez G.P., 1994: Vizualization of trends and fluctuations in climatic records, Water Resources Bulletin 30 (2), 297-306.

Helsel D.R., Hirsch R.M., 1992: Statistical Methods in Water Resources, Studies in environmental science, Elsevier, Amsterdam, The Netherlands.

Kundzewicz Z.W. 2004: Searching for a change in hydrological data, Hydrological Sciences Journal 49 (1), 3-6.

Kundzewicz Z.W., Robson A.J., 2004: Change detection in hydrological records - a review of the methodolo gy, Hydrological Sciences Journal 49 (1), 7-19.

Maradin M., 2011: Geographical Aspect of Differences in Precipitation Variability of Continental and Maritime Pluviometric Regimes in the Republic of Croatia, Doctoral thessis, University of Zagreb, Faculty of Science (in Croatian).

Maradin M., 2012: Spatial Differences in Precipitation Variability of Central Croatia, Croatian Geographical Bulletin 74, 41-59 (in Croatian).

Pandžić K., Trninić D., Likso T., Bošnjak T., 2009: Long-term variations in water balance components for Croatia, Theoretical and Applied Climatology 95, 39-51.

Prohaska S., Ristić V., 2002: Hydrology through theory and practice, $2^{\text {nd }}$ ed., University of Belgrade, Faculty of Mining and Geology, Serbia (in Serbian).

Reimann C., Filzmoser P., Garrett R., Dutter R., 2008: Statistical Data Analysis Explained: Applied Environmental Statistics with R, John Wiley and Sons, Chicester, England.

Shaw E.M., Keith J.B., Chappel N.A., Lamb R., 2010: Hydrology in Practice, $4^{\text {th }}$ ed., Spon Press, New York, USA.

Steiger R., 2010: The impact of climate change on ski season length and snowmaking requirements in Tyrol, Austria, Climate Research 43, 251-262.

Šegota T., Filipčić A., 2007: Contemporary climate changes and decrease of Sava river flow through Zagreb, Geoadria 12 (1), 47-58.

Trninić D., Bošnjak T., 2009: Characteristic discharges of the Sava River at Zagreb, Hrvatske vode 17 (69/70), 257-268 (in Croatian). 
Ulaga F., 2002: Trends in discharge changes of Slovenian rivers, Dela 18, 93-114 (in Slovenian).

Ulaga F., Kobold M., Frantar P., 2008: Trends of River Disharges in Slovenia, Earth and Environmental Science 4, 1-13.

Walford N., 2011: Practical Statistics for Geographers and Earth Scientists, Wiley-Blackwell, Chicester, England.

Zaninović K., Gajić-Čapka M., 1999: Changes in Components of the Water Balance in the Croatian Lowlands, Theoretical and Applied Climatology 65, 111-117.

Žganec K., 2011: The effects of water diversion and climate change on hydrological alteration and temperature regime of karst rivers in central Croatia, Environmental monitoring and assessment, September.

Žugaj R., 2000: Hydrology, University of Zagreb, Faculty of Mining, Geology and Petroleum Engineering, Zagreb, Croatia (in Croatian).

\title{
SOURCES
}

Deutsches Nationalkomitee für das IHP (UNESCO), Koblenz, Germany.

FAO AQUASTAT, Country Fact Sheet Croatia,

http://www.fao.org/nr/water/aquastat/data/factsheets/aquastat_fact_sheet_hrv_en.pdf (14 $4^{\text {th }}$ March 2012).

\section{SAŽETAK}

\section{Novije promjene srednjih godišnjih i sezonskih protoka rijeka u Hrvatskoj}

\author{
Ivan Čanjevac, Danijel Orešić
}

U istraživanju se analiziraju promjene srednjih protoka rijeka u Hrvatskoj na 53 hidrološke stanice s homogenim nizom podataka od 1990. do 2009. Na većini stanica zabilježen je negativan trend srednjega godišnjeg protoka, no on je u svega četiri slučaja statistički značajan. Izrazitiji pad primijećen je kod manjih nizinskih tekućica u unutrašnjosti Hrvatske, posebno u Slavoniji. Vjerojatno je da se njihova manja poriječja brže odazivaju na klimatske promjene koje su zabilježene od kraja 20. stoljeća u nizinskoj Hrvatskoj: blagi porast srednje godišnje temperature, pad količine padalina i vlage u tlu te porast potencijalne evaporacije (Zaninović i Gajić-Čapka, 1999). Usto varijabilnost padalina u unutrašnjosti Hrvatske raste od zapada prema istoku, što također utječe na protoke manjih tekućica.

Glavne rijeke kontinentske, unutrašnje Hrvatske (Sava, Drava i Mura) bilježe male promjene srednjih godišnjih protoka, što je prije svega posljedica promjena uvjeta otjecanja u uzvodnim državama Sloveniji (Frantar, 2003, 2005, 2007) i Austriji (Fürst i dr., 2008, 2010). Nešto veća promjena, odnosno porast srednjih godišnjih protoka, zabilježena je jedino u poriječju Kupe. To je posljedica porasta srednje godišnje temperature, smanjenja broja sniježnih dana te smanjenja trajanja sniježnog pokrova u tom području (Gajić-Čapka, 2011).

Analiza sezonskih promjena protoka pokazala je veću povezanost s promjenama klimatskih elemenata. Postoji jasan uzlazni trend protoka u proljeće, posebno tekućica koje se dijelom hrane 
sniježnicom, što upućuje na utjecaj sve toplijih zima s manje snijega, odnosno sa sve manjim udjelom snijega u odnosu na kišu u ukupnim zimskim padalinama. Jasno je da će to dovesti do smanjenja efekta retardacije u hladnom dijelu godine, te se protok preraspoređuje, a proljetni maksimum pomiče prema zimskim mjesecima. Ti trendovi i procesi sukladni su s onima u Alpama (Fürst i dr., 2010; Birsan i dr., 2005). Od svih mjeseci upravo je u ožujku zabilježen najveći trend porasta srednjega mjesečnog protoka.

Pad protoka u ljetnim mjesecima najizraženiji je na istoku i zapadu Hrvatske, kao i u planinskim krajevima. Na nekoliko dalmatinskih tekućica (Cetina, Krka i Vrljika) zabilježen je pak porast protoka, pretežno zahvaljujući porastu u kolovozu, koji nije statistički značajan. Na prvi pogled taj je rezultat oprečan rezultatima istraživanjâ koji pokazuju porast srednje godišnje temperature i pad površinskog otjecanja na dalmatinskoj obali od devedesetih godina 20. stoljeća (Gajić-Čapka i Zaninović, 2006). No u njima je riječ o temperaturnim podacima s obale, odnosno otoka Hvara, a u ovome istraživanju o tekućicama koje se dijelom hrane iz dinarskoga planinskog zaleđa, pa i podzemljem.

Gotovo uniformno zabilježen je pad protoka u jesenskim mjesecima, kao posljedica porasta ljetnih temperatura i evapotranspiracije te smanjenja količine padalina. Smanjenje količine padalina u jesenskim mjesecima, posebno u listopadu (Maradin, 2011) također izravno utječe na smanjenje protoka, posebno izraženo u studenome i zabilježeno na gotovo svim razmatranim stanicama. Ujedno je jesen godišnje doba s najizrazitijom varijabilnošću padalina u Hrvatskoj (Maradin, 2011). Općeniti trend sušnijih ljetnih i jesenskih mjeseci sukladan je s procesima u istočnoj Austriji (Fürst i dr., 2008, 2010).

U zimskim mjesecima bilježi se porast protoka na tekućicama u dijelovima Hrvatske s maritimnim pluviometrijskim režimom (Gorska Hrvatska, Istra i Dalmacija), a pad protoka (uz iznimku gornjeg toka Save) na tekućicama u dijelu Hrvatske s kontinentskim pluviometrijskim režimom.

Projekcije Svjetske meteorološke organizacije govore o padu protoka u Južnoj i Jugoistočnoj Europi od najviše 36\% do 2070. godine (Trninić i Bošnjak, 2009). Te se projekcije temelje na klimatskim modelima koji predviđaju daljnji porast srednje godišnje temperature zraka na Zemlji kao posljedicu daljnjeg rasta količine stakleničkih plinova u atmosferi. Nastave li se trendovi izloženi u razmatranoj studiji, možemo očekivati da to smanjenje protoka neće pogoditi sve tekućice u Hrvatskoj ravnomjerno. Vjerojatno je da će neke tekućice pokazati povećanje pojedinih mjesečnih godišnjih protoka i srednjega godišnjeg protoka. Valja uzeti u obzir smanjenje trajanja sniježnog pokrova i njegove debljine, što se predviđa za područje Alpa u 21. stoljeću, posebno na nižim nadmorskim visinama od 600 do $1300 \mathrm{~m}$ (Steiger, 2010). Preciznija predviđanja promjena klimatskih elemenata i njihovih posljedica na otjecanje tekućica zahtijevat će modeliranje na razini poriječja, što je zasad otežano neadekvatnim skalama klimatskih modela i nedostatkom podataka, odnosno nizova podataka o svim relevantnim prirodnim čimbenicima unutar poriječja.

Što se tiče promjena zabilježenih u ovome radu, nekoliko je mogućih posljedica za društvo i cijele ekosustave. Niži ljetni protoci nose opasnost povećanja koncentracije raznih polutanata u našim tekućicama, što uz povećane temperature vode ugrožava riječne ekosustave, te znače i smanjenje količine pitke vode raspoložive za vodoopskrbu i druge ljudske djelatnosti. Taj je problem posebno opasan za primorski dio Hrvatske, gdje su ionako više potrebe za vodom u ljetnim mjesecima još znatno izraženije zbog turizma. Povećanje protoka u proljeće, naglije topljenje snijega i veća varijabilnost padalina svakako povećavaju rizik od poplava, posebno od bujičnih brdskih i gorskih tekućica u kasnu zimu i rano proljeće. Promjene režima otjecanja svakako se moraju uzeti u obzir pri upravljanju vodnim resursima na svim razinama. 
Received (Primljeno): 2015-04-15

Accepted (Prihvaćeno): 2015-06-16

Ivan Čanjevac, $\mathrm{PhD}$, Senior Assistant University of Zagreb, Faculty of Science, Department of Geography Marulićev trg 19/II, Zagreb, Croatia canjevac@geog.pmf.hr

Danijel Orešić, PhD, Associate Professor University of Zagreb, Faculty of Science, Department of Geography Marulićev trg 19/II, Zagreb, Croatia doresic@geog.pmf.hr 